\title{
We Are Together Now: Notes on the Film Hoktiwe: Two Poems in Ishakkoy
}

\author{
Jeffery U. Darensbourg
}

check for updates

Citation: Darensbourg, Jeffery U. 2021. We Are Together Now: Notes on the Film Hoktiwe: Two Poems in Ishakkoy. Genealogy 5: 28. https://doi.org/10.3390/ genealogy5020028

Received: 9 February 2021

Accepted: 22 March 2021

Published: 25 March 2021

Publisher's Note: MDPI stays neutral with regard to jurisdictional claims in published maps and institutional affiliations.

Copyright: (C) 2021 by the author. Licensee MDPI, Basel, Switzerland. This article is an open access article distributed under the terms and conditions of the Creative Commons Attribution (CC BY) license (https:// creativecommons.org/licenses/by/ $4.0 /)$.
Enrolled Member Atakapa-Ishak Nation, New Orleans, LA 70119, USA; jefferydarensbourg@gmail.com

\begin{abstract}
Artist and historian of the Atakapa-Ishak Nation, Jeffery Darensbourg's 2020 film with Fernando López features poetry in Ishakkoy, an indigenous language from what is now southwest Louisiana and southeast Texas, composed during an artist residency at A Studio in the Woods. The companion essay shares some of the process of composing creative works in this language, and especially of writing centos, also known as patchwork or collage poems, during COVID-19 sequestration.
\end{abstract}

Keywords: Atakapa-Ishak; Ishakkoy; language reclamation; indigenous poetry; indigenous film; A Studio in the Woods

I had plans and plans in March of 2020 when I arrived for an artist residency at Tulane University's A Studio in the Woods, a sylvan retreat on the West Bank of Orleans Parish, Louisiana. I was working on a book. I am still working on that book, a book of essays. The specific residency I had earned was known as an Adaptations Residency, set up to promote the creation of work about adapting to climate change, environmental destruction, and coastal erosion. For me, it was about adapting in a different way, as I soon found myself alone.

Other residents canceled due to COVID-19 concerns, staff showed up less frequently, and I spent many days by myself as the only human being on a beautiful campus of forest and water accompanied by tricolored herons, plain-bellied water snakes, an armadillo who traipsed under the kitchen window promptly at 8:00 p.m. every evening, and a baby alligator who sat on a fountain in the pond there perpetually looking at me. I named the alligator Nesh Kok, "crooked stick" in the language of my tribe, the Atakapa-Ishak Nation, a language called Ishakkoy by tribal members, and known incorrectly as Atakapan by others. In the mornings, as I walked from the main house to the studio, I would sing a song for Nesh Kok that I had composed:

Neš Kok, cici Neš Kok

cici šiwat, yil tol, Neš Kok

$\mathrm{Ne}-\mathrm{Ne}-\mathrm{Neš} \mathrm{Kok}$, Ne-Ne-Neš Kok

cici šiwat, Neš Kok!

Nesh Kok, baby Nesh Kok

baby alligator, good day, Nesh Kok

Ne-Ne-Nesh Kok, Ne-Ne-Nesh Kok

baby alligator, Nesh Kok!

During the residency, I had intended to do field research, visit archives, and conduct personal interviews. That was simply not possible. Archives were closed and travel was ill advised. So, I read and read, and worked on my Ishakkoy. I used over 600 note cards I took while going through David Kaufman's Atakapa Ishakkoy Dictionary (Kaufman 2019) to compose poems and song lyrics. Inspired by cento, a sort of found poetry, I composed poems from example sentences in the dictionary, most of which came from Ishak people living in Tew Tul (Lake Charles, Louisiana) in the 1880s. Two of these poems became 
the text for the film Hoktiwe: Two Poems in Ishakkoy. The film was commissioned for a 2020-2021 exhibit at the Contemporary Arts Center New Orleans, "Make America What America Must Become," a title based on a passage from James Baldwin (Baldwin 1962). The first poem in the film, entitled "A Studio in the Woods", reflects my time there, away from others, but still feeling connected to them, including my friend Nesh Kok. The the second poem in the film, "Hoktiwe", means "we are together" in Ishakkoy, and is a cento, a type of found poetry, composed using example sentences from the Ishakkoy dictionary (Darensbourg 2020).

In making a film of these poems, I worked with Fernando López, a local artist I had collaborated with on one of my other projects, the zine Bulbancha Is Still a Place: Indigenous Culture from "New Orleans" (Schmelzer 2021). The visuals in the film were Fernando's idea. He filmed me recording the music at HighTower Studios, a place that was recommended by a friend who is a member of the metal band Thou. I composed the soundtrack, and played all the instruments-guitar, hand drum, and thunder tube-on the songs. Fernando also followed me through my walks around the banks of the river and bottomland forest connected to A Studio in the Woods, and then wove the footage from HighTower through it, turning the poems into a sort of music video. The scenes capture my loneliness during the time of my residency, a loneliness within which there were deep feelings of connectedness both to nature and other people whom I chatted with, read, or read about. Composing the poems with words from far distant tribal cousins was an incredible experience, as was working with both Fernando and sound engineer James Whitten. As for Nesh Kok, we wanted to put them in the film. In keeping with their mischievous nature though, on the day of the filming they did not show up.

Funding: This research received no external funding.

Institutional Review Board Statement: Not applicable.

Informed Consent Statement: Not applicable.

Data Availability Statement: Not applicable.

Acknowledgments: I would like to extend a hearty hiwew (thank you) to Rachel Breunlin, Fernando López, Ama Rogan, Joe Carmichael, Grace Rennie, Dave Baker, Cammie Hill-Prewitt, and A Studio in the Woods for making this writing possible.

Conflicts of Interest: The author declares no conflict of interest.

\section{References}

Baldwin, James. 1962. A Letter to My Nephew. The Progressive, January 1.

Darensbourg, Jeffery U. 2020. Hoktiwe (for L. Rain Prud'homme-Cranford). Transmotion 6: 138-41.

Kaufman, David V. 2019. Atakapa Ishakkoy Dictionary. Chicago: Exploration Press.

Schmelzer, Paul. 2021. Bulbancha Forever: From NOLA to Minneapolis, a Movement to Revitalize Indigenous Names Grows. The Ostracon. January 4. Available online: https:/ / theostracon.net/bulbancha-indigenous-naming-jeffery-darensbourg/ (accessed on 6 February 2021). 